\title{
Anticoncepción y género en Europa durante la segunda mitad del siglo XX
}

\author{
Contraception and gender in Europe in \\ the second half of the twentieth century
}

\author{
María Jesús Santesmases \\ Investigadora, Departamento de Ciencia, Tecnología y \\ Sociedad/Consejo Superior de Investigaciones Científicas. \\ mariaj.santesmases@cchs.csic.es
}

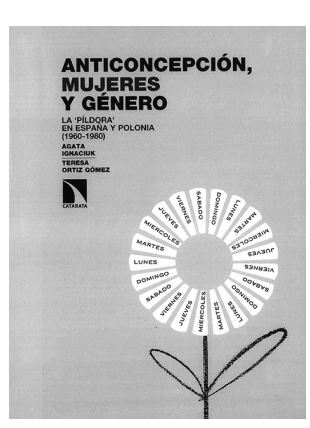

IGNACIUK, Agata; ORTIZ GÓMEZ, Teresa. Anticoncepción, mujeres y género: la píldora en España y Polonia (19601980). Madrid: Catarata. 2016. 240p.
$\mathrm{L}$ a historia que Agata Ignaciuk y Teresa Ortiz Gómez han escrito sobre este conjunto de objetos médicos que son los anticonceptivos hormonales y su conexión con las culturas sobre los cuerpos y la reproducción encaja este libro entre los pioneros sobre fármacos, género y mujeres. La historia de los medicamentos es muy reciente, así lo muestra la bibliografía exhaustiva de este libro construido a través de las mujeres. Las mujeres son aquí agentes de la historia: esperaban, compraban, pedían, deseaban no embarazarse o si lo hacían, cumplían sus deseos, no se sometían.

Trata de la píldora en España y en Polonia, aunque no es una historia comparada al uso sino una aportación al rompecabezas de un modo de historizar género y fármacos que es poscolonial en el sentido de que no acepta, sin discusión, los liderazgos geopolíticos del conocimiento de la posguerra en Europa y las Américas como influencia insoslayable y fatal

del norte sobre el sur y sobre el este del continente. De ahí su interés para una lectura desde América Latina porque explora particularidades nacionales de una historia de la anticoncepción en la que participaron la autoridad médica y la autoridad de las mujeres.

La historia de los anticonceptivos orales se narra como colectiva, de colectivos activistas. En un acto reflexivo de mucho interés analítico, el libro resulta activista, como buen producto del feminismo académico. Mujeres españolas y polacas comparten protagonismo con la píldora, esa mercancía de la industria farmacéutica que ha quebrado la función médica y su relación con las pacientes y que evoca la consulta médica como ventanilla burocrática y el reconocimiento médico para expedir recetas como trámite obligado, impuesto por la sociedad patriarcal a cambio de un pedazo de libertad. El texto incluye cronologías de leyes y aprobación de derechos en España y Polonia, datos detallados de importación, producción industrial y publicidad. 
Tras una introducción excelente que repasa la historiografía de la píldora y de las políticas reproductivas y su relación con la práctica médica en Polonia y en España, el texto recompone el trayecto de los denominados anovulatorios - otro de los nombres que recibían los anticonceptivos - de la dictadura del general Franco a las políticas de planificación familiar en España, de la producción industrial de estos fármacos en España y en Polonia a las limitaciones de los mercados nacionales en plena circulación internacional de estos medicamentos orales. En esos envases viajaban conocimiento y prácticas médicas, sus efectos de supresión de la ovulación y de regulación de la menstruación, su relación con las políticas del aborto en Polonia y con el poder médico en España, todo lo cual se analiza en el tercer capítulo. El cuarto se dedica a las imágenes publicitarias que exhibían los estereotipos vigentes de género - anuncios que muestran a mujeres casadas, con su prole en el regazo y el anillo en el dedo, muy atentas al consejo médico. El capítulo quinto se dedica al protagonismo de las mujeres en esta historia, con testimonios de quienes las consumieron y quienes no, los recuerdos sobre el control médico y su relación en Polonia con una política de control de la natalidad que tenía en el acceso al aborto uno de sus pilares.

La historiografía de las píldoras anticonceptivas - los anticonceptivos orales son los medicamentos mejor estudiados con perspectiva de género hasta ahora - interacciona con este mismo texto y contribuye a reforzarlo. El tratamiento del mercado - la oferta y la demanda en la base de esta mercancía influyente del capitalismo -, la publicidad, y en general, las estrategias de promoción de la industria farmacéutica funcionaron en permanente cooperación con la autoridad médica de forma que esta vio reforzado su poder a cada paso, al convertirse en barrera para entrar en el mundo autorizado de la receta, imprescindible para adquirir estos fármacos. El manejo del eufemismo terapéutico por el poder obstetra y ginecológico - que promovía el consumo de la píldora para la regulación del ciclo menstrual mientras trataba de ocultar sus efectos anticonceptivos - aparece interesado en el sometimiento de los cuerpos de las mujeres. El libro sitúa los anovulatorios hormonales en la historia larga de las culturas de las mujeres en lo que atañe a su control sobre la reproducción en la era de la invención del amor de pareja y maternal como sostén de la estructura social.

El texto abre muchas puertas. Entre las más emotivas, aunque no sean singularidad exclusiva de este libro, son las fuentes orales como conjunto de encuentros irrepetibles, que evocan subjetividad y, otra vez, reflexividad. El factor emocional opera como articulador de preguntas y de respuestas, a lo que se añade el poder de los anovulatorios en la estandarización del ciclo menstrual. Se trata de temporalidades industriales impuestas a los cuerpos y sus fisiologías en un tiempo de internacionalización de los mercados, que penetraban en la industria, la economía y la cultura. Al peso de la religión como poder acompañante se le dedican las páginas que merece. Las historiadoras de la ginecología han explorado este asunto y la extraordinaria sensibilidad del poder médico por la autoridad política en Europa. La acción anovulatoria funcionaba como acto social, y se podría añadir, de geografía cultural; argumentos estos, los geográficos, inmersos en la lectura crítica, que el propio libro propone, de esta completa historia transnacional de fármacos y género.

Dirigido a un público amplio, interesado en la historia social y política de la medicina, las mujeres y el género, su logro principal es no sólo historiográfico sino también metodológico y discursivo, pues muestra una forma de investigar y relatar con perspectiva de género y mucha erudición histórico-médica. 